was the time of the Berlin crisis, the quarrel with Yugoslavia, and a fresh outbreak of purges and trials. He probably also felt that he was no longer revealing decisions and plans made by some remote authority, but plans he had helped to make and with which he agreed. Fuchs seems to have shared fully in the euphoric feeling at the time that nuclear power would save the world from want. For whatever reason, he stopped giving information early in 1949. Then his father was appointed to a professorship in East Germany. Fuchs suddenly felt that his close links with his father would make him vulnerable not only as a security risk, but as an openly apparent one too. So he went to talk to the security man at Harwell Henry Arnold.

Meanwhile, the Americans had managed to decode some messages sent from New York to Moscow back in 1944. One of these pointed to a leak, and to Fuchs as the source. So Arnold had been already alerted, and for some time had cultivated a close friendship with Fuchs. With Skardon of MI5 he now set about inducing him to confess. Fuchs had experienced the bully-boy methods of the Nazis, but was quite unprepared for the tender-lovingcare and friendly-cup-of-tea approach adopted by the wily Skardon. He confessed, and gave a complete list of his disclosures and a description of his contacts. Up to this point the authorities had only known that there had been a leak. Now they found to their horror that nearly every aspect of the project had been disclosed.

After that the trial and conviction were a foregone conclusion. What hurt Fuchs most was that his naturalization was revoked, and it was only then that he told Skardon that he was not really a friend. He earned the full remission of his sentence by good behaviour, was released in 1959 , and went to East Germany to rejoin his aged father, and to marry. He was given a senior post in an atomic research institute from which he retired in 1979, covered in honours from a grateful government.

To most Western commentators the period of Fuchs's confession and cooperation with the security services is an interval of normal, right-thinking behaviour in an otherwise deplorable career. To Fuchs things would probably be the reverse. $\mathrm{He}$ would regard this period as a brief aberration in a life otherwise devoted to a noble cause. Norman Moss has made a contribution to bridging this gap in perceptions, and has written the best biography of Fuchs so far.

Alan Nunn May was a member of the BritishCanadian atomic project in Montreal from 1943 to 1945 . He was convicted of giving the Russians information in 1946 and sentenced to ten years in prison. In 1961 he was appointed Professor of Physics in the University of Ghana, and retired in 1978.

\section{Bishop's vision}

\section{F. Land}

Visual Neuroscience. Edited by J. D. Pettigrew, K. J. Sanderson and W. R. Levick. Cambridge University Press: 1986. Pp. 448. £75, \$125.

Visual Neuroscience arose as a Festschrift for Peter Bishop, the unlikely setting being a church hall on Lord Howe Island, in the Tasman Sea. Bishop's career spans the whole post-war period of visual physiology, and our present knowledge of the visual pathways owes as much to the work of his laboratory and those of his students as it does to the pioneer studies of Hubel and Wiesel.

Bishop's own work in vision began in the 1950 s with an analysis of the circuitry of the lateral geniculate nucleus, and developed from there into a long series of studies on the nature of binocular vision, and the interactions between the eyes in both geniculate and cortex. In his research papers, Bishop comes across as careful, even cautious, but with a highly inventive methodological streak. He developed much of his own apparatus, and his laboratories were always superbly equipped. Outside his immediate research, Bishop's interests broadened to extend over the whole of vision, and indeed the first paper he admits to, in 1939, was on the nature of consciousness. Arguably, Bishop's real legacy was his students; no less than 25 are now full professors around the world, a statistic that can have few competitors. As Horace Barlow succinctly puts it in his contribution: “. . . it was not until I collaborated with Bill Levick in the 1960's that I discovered how the professionals - trained by Peter Bishop - did it"

The book has six sections, beginning with the retina and ending with visual psychology, together with several appreciations of Peter Bishop's career and his full bibliography. It begins with a characteristic chapter by Barlow called "Why Can't the Eye See Better?" - an entertaining re-evaluation of the physical and neural limits to vision. There follow a number of reviews (by Wässle, Levick, Burke, Henry and Kaas) dealing with one of the most important themes of the Bishop school: the X, Y, W classification of retinal ganglion cells and the way this division is maintained through the geniculate and cortex. Kass links the $\mathrm{X}$ and $\mathrm{Y}$ systems to the "two cortical visual systems" of Ungerleider and Mishkin; the slow, fine-grain $\mathrm{X}$-system leading to recognition in the temporal lobe, and the faster, coarser Y-system subserving orientation in the parietal lobe. There is a short comparative section in which Pettigrew examines binocular vision in cats and owls, and Aitkin contrasts processing in the visual and auditory areas. The final section, "Integrative Aspects", contains a nice pair of papers in which Day explores the phenomenon of illusory contours and Peterhans and her colleagues show how end-stopped cells in the pre-striate cortex can respond to such contours.

The most abiding contribution of Bishop's disciples has been their elucidation of the parallel nature of visual processing, contrasting with the serial hierarchy of the Hubel and Wiesel approach. Visual Neuroscience is a considered statement of that position, and is essential reading for all those concerned, at the research level, with the way the brain sees.

M. F. Land is Professor of Neurobiology in the School of Biological Sciences, University of Sussex, Brighton BN1 9QG, UK.

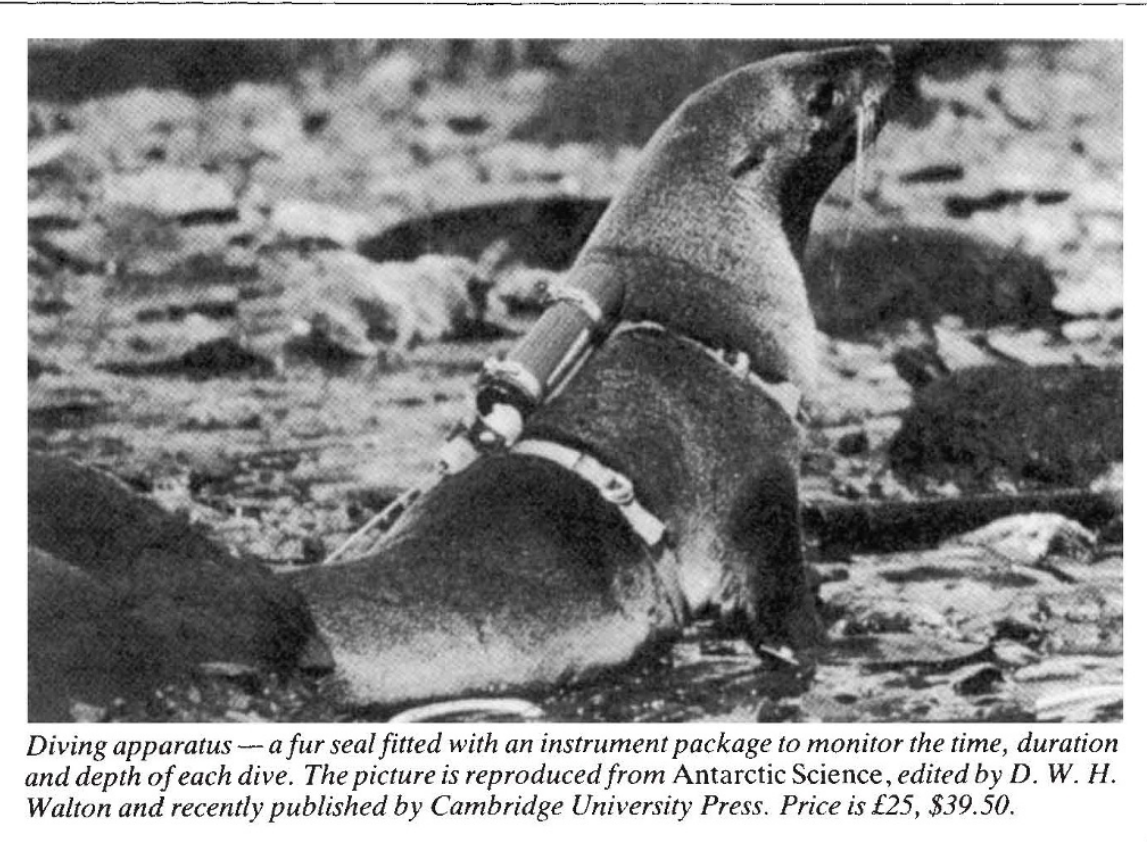

